ISSN: 2349-2031

(C) 2018, THEIJSSHI

Research Article

\title{
Critical Pedagogy in Egalitarian School Culture
}

\author{
Lusila Andriani Purwastuti
}

The Faculty of education, Yogyakarta State of University, Yogyakarta, Indonesia

\begin{abstract}
Critical pedagogy and egalitarian school culture were two concepts that cannot be separated. The concept of critical pedagogy was still difficult to accept by Indonesian education philosopher, let alone implemented in schools.This research's purposes were to explore empirically the background of the egalitarian culture of SMA 3 Yogyakarta, reflecting it and conceptualizing the democratization of education. A qualitative approach was used in this study, a type of phenomenological research. Interviews, observations, and documentation were used as data collection techniques. Data analysis techniques used Miles and Huberman with the steps of data condensation, data presentation, verification, and conclusion. Data validity used to source and technique triangulation. Research shows that the background of an egalitarian culture is students, teachers, learning, alumni, and the environment. The ideology of education is three concentric, which is a combination of three conservative, liberal and critical ideologies. Educational ideology is in precritical education, while the educational democracy conceptualization is an educational process that has an egalitarian culture embryo built with a critical paradigm that fulfills democratic requirements (openness, kinship, partnership). The conclusion that can be drawn from this research is critical pedagogy and egalitarian culture is a process that must occur in schools to actualize the educational democratization. The critical pedagogy praxis in Yogyakarta 3 State Senior High School can be used as a model to actualize democratic citizens and educational praxis that humanize humans.
\end{abstract}

\section{Keywords: Educational Ideology; Critical Pedagogy, School Culture.}

\section{[1] Introduction}

Egalitarian/democratic school culture supported the actualization of national education goals. The National Education System in 2003 article 3 stated that the national education aim was that National Education functions to develop the competence and shape a dignified nation character in the framework toenrich the life of the nation, aiming at developing the potential of students to become faithful and devoted to God Almighty, noble, healthy, knowledgeable, capable, creative, independent, and democratic as well as responsible citizen. The national education purpose included the whole Indonesian people development (including social literacy) according to the 1945 Constitution mandate, namely to educate the nation's life which included the basic quality development (power of thought, heart power, physical power), instruments quality (mastery of science, technology, art, and sports to meet the Indonesia's interests), the quality of Indonesian related (Pancasila, UUD'45, NKRI, and Bhinneka Tunggal Ika), and global quality.

Intolerance was a problem that was directly related to egalitarian culture [1]-[3]. Intolerance was sweeping Indonesia and the world lately. Report from The Fund for Peace [4] which said that the increasing intolerance, especially in relation to religion and belief in Indonesia. The conflict had been considered as a mode to shed any frustration and disappointment that occurred in society. Conflicts between community groups in Indonesia, both vertically and horizontally, often occurred in several regions. In fact, Indonesia has 34 provinces, but unfortunately, 14 provinces were areas that are often hit by conflict [5]. The conflict in the Middle East was a conflicting example due to intolerance which later developed into an increasingly widespread conflict involving various countries in it.

This egalitarian/democratic school culture occurred in communication, interaction processes, daily behavior between school residents and existing artifacts in both academic and non-academic aspects. The egalitarian culture was impossible established in a short period of time and was the result of an individual's views or values.However, this culture manifested itself from various values / ideological systems that interact with one another between school residents, both principals, teachers, employees, students, alumni for a long time. This meant that the manifested culture was adialectical process accumulation and the dynamics of various ideologies or views/thought concepts of its citizens.

Egalitarian culture could not be separated from the critical educational ideology. In egalitarian culture/democracy freedom to be different in all contexts including opinions as the culture was a way to live together and unite [6]. While the critical education ideology was an educational paradigm that aimed to actualize students' critical awareness. Students who had freedom from domination and oppression because of the power relations that occurred at school. This paper would examine empirically a schooling phenomenon as a fundamental research that aimed to explore the background of the occurrence of egalitarian/democratic culture in a school. Reflections on this background obtained the educational ideology concept and educational democratization conceptualization. The research results become findings or embryos for the next research which is the contextual model of Critical Education Praxis development with Indonesian culture.

Kiraz, E. \& Ozdemir, D [7], entitled "The Relationship between Educational Ideologies and Technology Acceptance 
in Preservice Teachers". This study explored how the educational ideology influences the technology used in the classroom. Although many models and theories had tried to explain the factors that contribute to technology acceptance, most models and theories had focused on factors related to technology. This research focuses on educational ideology, factors that are not related to technology which also influence decisions in terms of educational applications. This study outcome illustrates that different educational ideologies have different effects on teacher technology acceptance.

Chantarath Hongboontri and Natheeporn Keawkhong [8] from Mahidol University, Thailand. This research entitled "School Culture: Teachers' Beliefs, Behaviors, and Instructional Practices" which explored the culture of Hope University's Language Institute and reveals the interrelationships between school culture as well as the of learning English practice as a foreign language. Quantitative data showed a strong correlation between eight organizational social variables of school culture. Qualitative data further revealed the influence of school culture on the teacher's learning practices.

Lori T. Meier [9] "The Effect of School Culture on Science Education and Ideologically Innovative Elementary". This ethnographic case study investigated teacher practice in one of the public primary schools in seeing how school culture influenced the curriculum design of science and learning. The resulting data, triangulated with informal observations and collections of artifacts, were analyzed using a theoretical framework that emphasized five interrelated indicators of school culture: 1) values; 2) confidence; 3) practice; 4) ingredients; and 5) problems. The findings indicate that a bad school culture will affect the treatment of science at school.

\section{[2] Methods}

This studywas a qualitative research approach. This research'stype was phenomenology. Research subjects were principals, teachers, students, and alumni. The research objectwas the background of egalitarian culture in Yogyakarta 3 State High School, educational ideology, and conceptualization of education democratization. Data collection techniques were used in interviews, observation, and documentation. Interview data analysis techniques using interpretive with the following steps: This research used the data analysis process of Interpretative Phenomenological Analysis by Smith [10] which included: 1) reading and rereading, meaning reading repeatedly the results of in-depth interviews; 2) initial noting, meaning making notes on transcripts of interviews. A textual analysis was free to provide a comprehensive and detailed set of records of data; 3 ) Developing Emergent Theme, a simultaneous analysis of transcripts from interviews that had been given comprehensive and detailed records. A mapping activity against the interview's overall result. A reorganization data to find clarity on the relationship between one theme and another; 4) Searching for connection across emergent themes, meaning searching for relationships and cross-analyzing between one theme and another, so that you can find organization between themes. Organizing themes would produce a meaning from sketches of emerging and mutually compatible themes. Interpretative phenomenology analysis would produce abstraction, conclusions, polarization, contextualization, chronologization, and functionalization; 5) Moving the next case. The researcher would do the first analysis up to the fourth in the interview transcript from other informants; 6) Looking for the pattern across cases.

After the researchers conducted an analysis of the all informants' interviews transcripts, furthermore the researchers conducted an analysis to find patterns. Analysis to find patterns/descriptions or views configurations/ concepts/education ideologies owned by school citizens to actualize egalitarian culture. While the observation and documentation data were analyzed using the Miles and Huberman theory [11] with the steps of condensation, data presentation, verification, and conclusions. Abstraction analysis used Aristotle's abstraction theory which includes removing things that happen to exist (axidensia) to find substance. The inter-theme analysis would find conceptualization of education democratization. The validity of the data used triangulation of sources and techniques.

\section{[3] Results and Discussion}

\section{a. Result}

These study results indicate that there are five components underlying the egalitarian culture, namely: teachers, students, learning, alumni, and the environment. These five components contributed greatly to egalitarian culture in Yogyakarta State Senior High School 3. High school students come from junior high school students who are smart but have artistic, sports and expressive talents. Input from Yogyakarta State Senior High School 3 comes from children who have a high NEM (Indonesia's Graduation Assessment Test scores) of their favorite junior high school in Yogyakarta. Teachers have contributed to an egalitarian culture. High school teacher 3 has a perspective on the educators' concept. Education is a process of humanizing humans. The teaching and learning process is carried out in the classroom, school environment, community. Learning is meant to learn together. The natural and physical (spatial) environment, as well as the socio-cultural environment both in school and outside the school, are learning resources. School is a living space that is always turned on and lived by the school. Alumni contribute greatly to egalitarian culture in schools. Many Padmanaba alumni become successful citizens. They have leadership positions in both the private and government sectors. These five components synergize with each other and have a relationship in school welfare, as can be seen in the following figure,

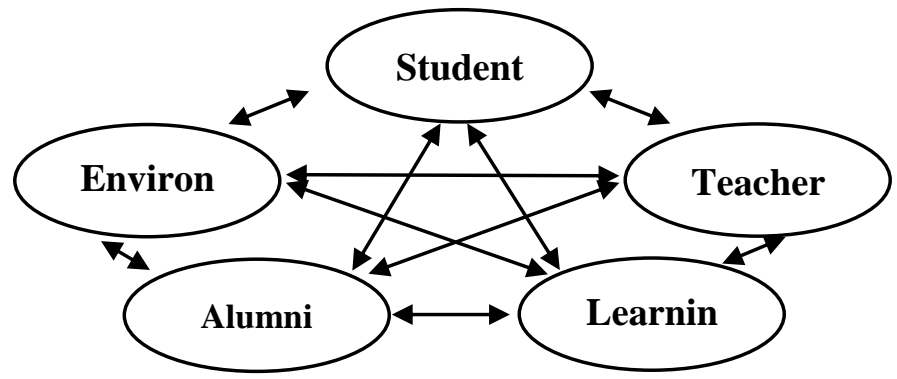


Figure 1. The relationship form of the five components forming an egalitarian culture

The reflection results on egalitarian cultural components consisting of students, teachers, learning processes, alumni and the environment show that the educational ideology of Yogyakarta State 3 Senior High School is a tri-centric (three concentric) between conservative ideology, liberal ideology, and critical ideology. The educational ideology of SMA Negeri 3 Yogyakarta is in the pre-education stage of criticism. This school has opened school barriers, explored and studied real-life issues through the event..

\section{b. Discussion}

\section{Background of Egalitarian Culture in Yogyakarta State Senior High School 3}

The background of the egalitarian culture of SMA Negeri 3 Yogyakarta can be classified into aspects, namely students, teachers, teaching and learning process, alumni, and environment. These five components contributed greatly to egalitarian culture in Yogyakarta State Senior High School 3. These high school students come from junior high school students who are smart but have artistic, sports and expressive talents. Input from Yogyakarta State Senior High School 3 came from children who have a high NEM (Indonesia's Graduation Assessment Test scores) of their favorite junior high school in Yogyakarta. Therefore, the talent or natural nature that is owned becomes the main capital or material to actualize its egalitarian culture. In addition, a large number of parents' background is a lecturer profession, so they provide a lot of support for learning facilities such as IT and books available at the home library. Various studies in various countries have proven that parents' background in terms of work and education, positively adhere to parenting, patterns of learning, aspirations, and parental participation in children's education [12]-[15]. This is also the case in Yogyakarta State Senior High School 3. The culture of self-learning is creative thinking, critical, democratic and has been brought from the family. This capital contributes to school events. They can negotiate with other people, find sponsors, and advertise their events.

Teachers have contributed to an egalitarian culture. Teachers at SMA Negeri 3 Yogyakarta have a perspective on the educating concept. Education for them is a process of humanizing humans [16]. The teachers prioritize education that is centered on students. They also hold the system among [16] which places the teacher as a facilitator, who is independent and gives freedom to students. The freedom granted is a form of responsible freedom. This is because the teachers hold a principle in educating, namely the balance between academic values and values that are useful for students' lives and lives, independence but not an underestimation. The teachers try to act as parents in school, but with a politeness limit. Decency is a limitation when the teacher interacts with students, and vice versa. Teachers are able to build students' trust in themselves. This is very important because politeness will only be actualized when the interacting individuals have mutual trust [17]. All of this is the teachers' educational conceptionessence.

Learning does not need to occur only in school buildings, the environment outside the school has great potential in creating a learning environment that is rich in learning resources [18], [19]. This is also the case in Yogyakarta State Senior High School 3. The teaching and learning process is not only carried out in the classroom, but also the school environment, and the community environment. Learning is interpreted as learning together. Student learning resources are not only teachers but also social events, community life, and alumni. Learning methods that are often used include dialogue (discussion), contextual (bringing the concept closer to the real thing), problem-based learning (learning from real life: communityissues, schoolyard, school canteen), project learning (talk a little work). One of the authentic learning resources at SMA 3 Yogyakarta is school events. School events held and planned by students become a source of learning for life and existence.

This event is intended so that students have a responsible leadership spirit and can organize or manage the organization. Arent et al. [20] suggested that leadership practice scores and student leadership behaviors increased after managing events/events. In addition to managing this school event, students are also trained in entrepreneurship, because when they hold an event they must be able to find funds to fulfill the event. Schools only provide small financial assistance (School Expenditure Budget for various limited events). Event and festival activities are one of the school's media to teach about diversity that exists in the Indonesian nation and schools in particular. Through this activity, they will meet, hang out, and collaborate with various individuals from different backgrounds. The spirit of recognizing, appreciating and collaborating with those who are indirectly different is that they live and internalize in students. The high social sensitivity and ability to socialize greatly affect the leadership spirit of the students [21]. This also influences the way in which school citizens respond to various values or outside cultures that are not in accordance with school values, namely not reactively rejecting.

Alumni contribute greatly to egalitarian culture in schools. Various studies have also proven the alumni's rolemagnitude in building and improving the schools'quality in various forms such as marketing, donations, and also mentoring for students [22]-[25]. Many Padmanaba alumni (SMA Negeri 3 Yogyakarta) are successful citizens. They have leadership positions in both the private and government sectors. Many school alumni who work as managers of private and state companies, some become ministers in the New Order government and the Reformation era. Even this school alumni are the most famous alumni of their solidarity. Alumni from the Padmanaba Alumni Big Family Institute which covers funds to provide educational assistance to schools (laboratory equipment, books, and infrastructure facilities that become school needs) as well as providing scholarships for the sons and daughters of employees and teachers as well as students from disadvantaged families. Scholarships are a form of alumni care for students who excel but their parents are poor, 
the aim is to encourage the students. In each Padmanaba birthday event, they came to school to reunite and fill activities in the art night, and other activities.

The natural and physical (spatial) environment, as well as the socio-cultural environment both in school and outside the school, are learning resources. School is a living space that is always turned on and lived by the school. School residents and alumni develop schools by utilizing the environment in a quality school with various academic and non-academic achievements. School residents live from a variety of meaningful experiences in school both curricular, extracurricular and intracuricular. The environment including the atmosphere (school climate) becomes a vehicle for learning their lives.
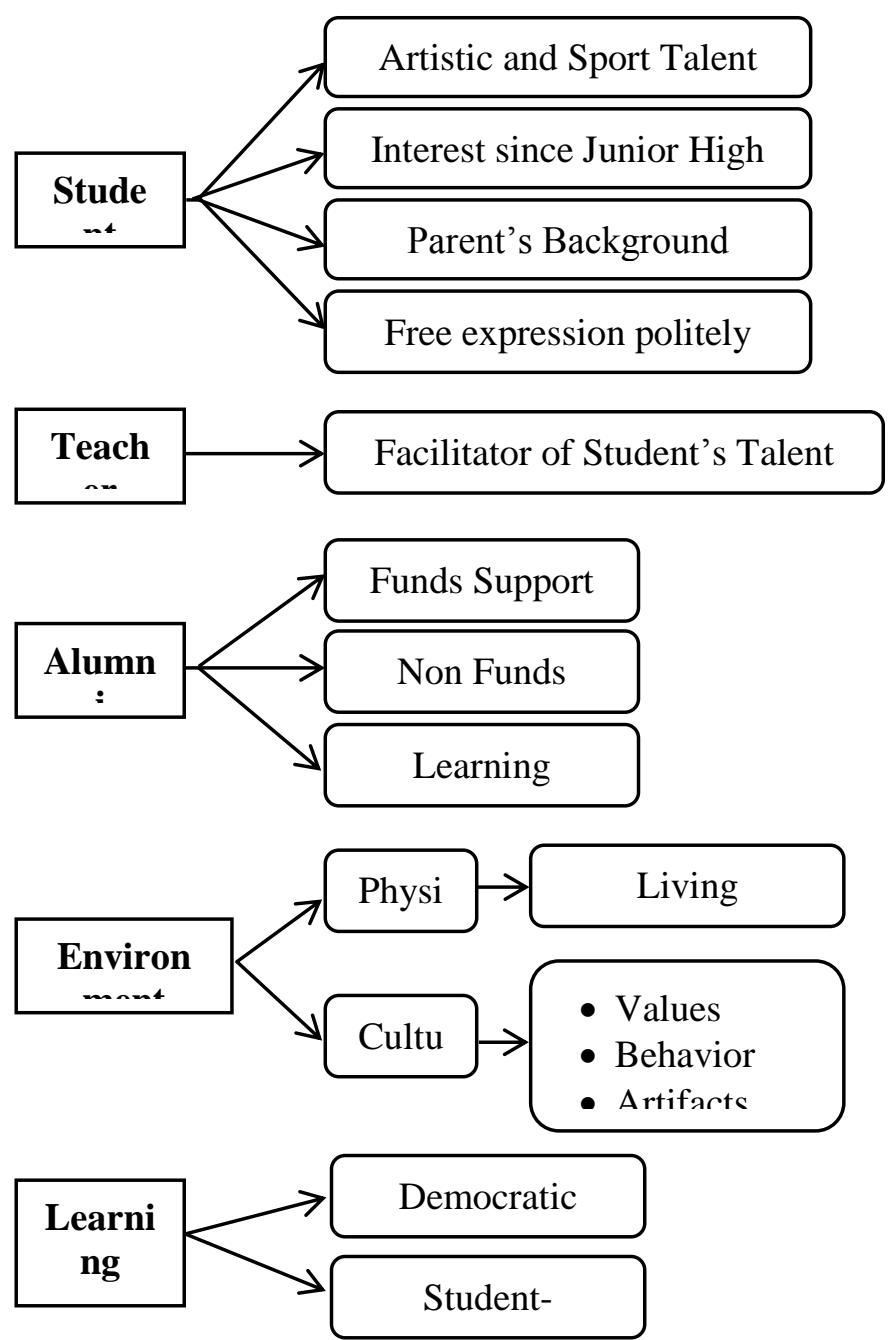

Figure 2. Component background chart underlying the egalitarian culture

\section{Ideological Education of SMA Negeri 3 Yogyakarta}

The reflection results against the egalitarian cultural components consisting of students, teachers, learning processes, alumni and the environment show that the ideological education of SMA Negeri 3 Yogyakarta is a three concentric between conservative ideology, liberal ideology, and critical ideology. Ideological education of SMA Negeri 3 Yogyakarta is at the critical education pre-existentstage. The indicator of conservative ideological education, namely discipline [26][27]. Discipline and obedience to the school rules they are still a school orientation. Presence is a tool for monitoring teacher attendance. Finger attendance is used in this school. Counseling teachers monitoring student attendance every day. Students who are absent from class for 3 days, their parents contacted by Whatsapp.

Ideological education of SMA Negeri 3 Yogyakarta is still at a pre-critical level [28], [29]. This school has opened school barriers, explored and examined the issues of real life through the event. They have been given the skills to disagree, empowering school citizens even though they have not yet to change an unfair public order. It is only to identify and describe the structural injustices that occurred in the community by bringing these issues to class to be reviewed, given the conclusion (class discussion, project learning, problem-based learning). Although the research paradigm and the assessment used are still using positivism. Students have been doing action/action in the form of visits to the sick and less fortunate (with charity program, scholarships), but has yet to do the training to the community to empower them. The actions have not yet come to the stage of critical actions that build a critical awareness.

\section{Conceptualization Democratization of Education}

Based on the analysis of the themes that exist in the study, it was found conceptualization of education democratization. The education democratization is a process of actualizing democratic education. Democratization of education can be actualized by creating an egalitarian culture in schools that use the critical education ideology paradigm to achieve critical awareness of school citizens (as an educational goal) with the communication conditions that is full of openness, kinship, service and compassion among school citizens, in addition there are no barriers in school. The physical and sociocultural environment becomes a living space that is turned on and sustained by school residents. The physical and social environment is a learning resource for school residents. School residents care about the injustices that occur in the community and the wider community.

Democratization is one of the ideals of reform. Openness and accepting differences are characteristics of democratization. Although the democratization shown in the school environment is still at the beginning of democracy. Schools have not fully had the freedom to interpret Pancasila. Pancasila is more interpreted for each schoolbenefit. This is understandable because schools are often sterilized from the nation and society life problems. Whereas schools as communities and institutions have an interest in interpreting Pancasila as an open ideology (education) because schools are a subjective place for implementing Pancasila for the young generation or young citizens

\section{[4] Conclusion}

There are five components of the egalitarian culturebackground: students, teachers, learning, alumni, and the environment. All components become the student learningsources. Alumni are a unique factor in realizing the egalitarian culture. An educational ideology of SMA Negeri 3 Yogyakarta is a tri-centric (three concentric) between 
conservative ideology, liberal ideology and critical ideology, which is at the critical pre-education stage: opening school barriers, engaging in community life, engaging in community activities: through school events. Democratization of education can be actualized by creating an egalitarian culture in schools that use the critical education ideologyparadigm to achieve critical awareness of school citizens (as an educational goal) with the conditions of communication that is full of openness, kinship, service and compassion among school citizensas well asthere is no border in school. This study is expected to give an overview to other schools in actualizing an egalitarian culture to realize one of the goals of education, namely democratic citizens, and also the input for education stakeholders in developing egalitarian/democratic education in high schools.

\section{Acknowledgment.}

Researchers would like to thank all parties who helped and supported the research and writing of this article.

\section{References}

[1] C. M. Oyamot, M. S. Jackson, E. L. Fisher, G. Deason, and E. Borgida, "Social Norms and Egalitarian Values Mitigate Authoritarian Intolerance Toward Sexual Minorities," Polit. Psychol., vol. 38, no. 5, pp. 777-794, 2017.

[2] A. Spector and B. Barry, "Culture and Equality: An Egalitarian Critique of Multiculturalism," Contemp. Sociol., vol. 32, no. 5, p. 592, 2003.

[3] A. Wright, "The Politics of Multiculturalism. A review of Brian Berry, 2001, Culture and equality: An egalitarian critique of multiculturalism," Stud. Philos. Educ., vol. 23, no. 4, pp. 299-311, 2004.

[4] The Fund for Peace, "Fund For Peace homepage," Fund for Peace website, 2018. [Online]. Available: http://global.fundforpeace.org/\%0Ahttps://en.wikipedia.or g/wiki/Fund_for_Peace.

[5] H. Soemantri, "Konflik dalam Perspektif Pendidikan Multikultural," J. Pendidik. dan Kebud., vol. 17, no. 6, pp. 660-672, 2011.

[6] D. Bir, O. Kültürü, İ. Y. Çerçevesi, M. Şişman, H. Güleş, and A. Dönmez, "Qualifications Framework For A Democratic School Culture," Uşak Üniversitesi Sos. Bilim. Derg., vol. 31, pp. 167-182, 2010.

[7] E. Kiraz and D. Ozdemir, "The relationship between educational ideologies and technology acceptance in preservice teachers," Educational Technology and Society, vol. 9, no. 2. pp. 152-165, 2006.

[8] C. Hongboontri and N. Keawkhong, "School culture: Teachers' beliefs, behaviors, and instructional practices," Aust. J. Teach. Educ., vol. 39, no. 5, 2014.

[9] L. T. Meier, "The Effect of School Culture on Science Education at an Ideologically Innovative Elementary Magnet School: An Ethnographic Case Study," J. Sci. Teacher Educ., vol. 23, no. 7, pp. 805-822, 2012.

[10] J. a Smith, "Interpretative Phenomenological Analysis," Existent. Anal., vol. 21, no. 2, pp. 186-193, 2010.
[11] M. B. Miles, A. M. Huberman, and J. Saldana, "Crosscase data analysis," in Qualitative data analysis: An expanded sourcebook, 2014, pp. 100-104.

[12]E. A. Hanushek, S. Machin, L. Woessmann, A. Björklund, and K. G. Salvanes, "Education and family background," in Handbook of the Economics of Education, vol. 3, 2011, pp. 201-247.

[13] A. Björklund and K. G. Salvanes, Education and Family Background. Mechanisms and Policies, vol. 3. 2011.

[14] M. Norberg-Schönfeldt, "Children's school achievement and parental work: An analysis for Sweden," Educ. Econ., vol. 16, no. 1, pp. 1-17, 2008.

[15] P. Glick, J. C. Randrianarisoa, and D. E. Sahn, "Family background, school characteristics, and children's cognitive achievement in Madagascar," Educ. Econ., vol. 19, no. 4, pp. 363-396, 2011.

[16] Ki Hadjar Dewantara, Bagian Pertama: Pendidikan. Yogyakarta: Majelis Luhur Taman Siswa, 1977.

[17] C. Lam, "Linguistic politeness in student-team emails: Its impact on trust between leaders and members," IEEE Trans. Prof. Commun., vol. 54, no. 4, pp. 360-375, 2011.

[18] B. Christie and P. Higgins, "Residential outdoor learning experiences and Scotland's school curriculum," Scott. Edu. Rev., vol. 44, no. 2, pp. 45-59, 2012.

[19] S. Beames, M. Atencio, and H. Ross, "Taking Excellence Outdoors," Scott. Edu. Rev., vol. 41, no. 2, pp. 32-45, 2009.

[20] S. B. Marcketti, S. W. Arendt, and M. C. Shelley Ii, "Leadership in action: student leadership development in an event management course," Leadersh. Organ. Dev. J., vol. 32, no. 2, pp. 170-189, 2011.

[21] S. Y. Yun and M. S. Kim, "Effect of the university student's sociality and empathic ability on the leadership life skills," Indian J. Sci. Technol., vol. 9, no. 46, 2016.

[22] C. Golz, "The Impact of Student Engagement on Alumni Giving," 2013.

[23] J. H. McAlexander and H. F. Koenig, "University Experiences, the Student-College Relationship, and Alumni Support," J. Mark. High. Educ., vol. 10, no. 3, pp. 21-44, 2001.

[24] T. S. Singer and A. W. Hughey, "The role of the alumni association in student life," New Dir. Student Serv., vol. 2002, no. 100, pp. 51-68, 2002.

[25]A. Petrovich and M. Lowe, "Developing Cultural Competence: Student and Alumni Perspectives," J. Teach. Soc. Work, vol. 25, no. 3, pp. 157-176, 2005.

[26] S. Selden, "Conservative Ideology and Curriculum," Educ. Theory, vol. 27, no. 3, pp. 205-222, 1977.

[27] G. Evans and J. Tilley, "Ideology," in The New Politics of Class, 2017, pp. 59-88.

[28] T. Smith, "Paulo Freire.," Paulo Freire - Res. Starters Educ., pp. 1-6, 2015.

[29]P. Freire, Freire: Education for critical consciousness. 2007. 